\title{
TEACHER'S MOTIVATION FOR MASTER DEGREE PROGRAM IN EDUCATIONAL SCIENCES IN LATVIA
}

\author{
Dita Nīmante \\ University of Latvia, Latvia \\ Maija Kokare \\ University of Latvia, Latvia
}

\begin{abstract}
Since October 2018 the University of Latvia alongside with three other higher education institutions (University of Liepaja, University of Daugavpils and Rēzekne Academy of Technologies) have been involved in the European Social Fund project 8.2.1 which aims to reduce the fragmentation of study programs in the field of education, pedagogy and sports in Latvia by closing a number of existing programs and developing new programs to provide conceptually new development of teacher-oriented teacher education in Latvia. As a part of the project the new Master level program "Educational sciences" being developed. The study aims identify teachers' motivations to study in the Master level program "Educational sciences". The study' s methodology included examining data both from interviews with the heads/ or deputies of the eight mainstream schools (different regions and types of schools), recent teachers with a Master's degree in general education, and surveys administered for educators and the students from bachelor level teacher education programs. As results indicate that the motivation of teachers to study in the Master level program is primarily intrinsic one which is consistent with international research. However, it would significantly facilitate studies if opportunities were provided to study for the state funded resources. Teachers extrinsic motivation to study the Master's level program in the education is closely associated with existing political, socio-economic, cultural and educational characteristics of Latvia's current state and demands from society.
\end{abstract}

Keywords: Master of Educational sciences, Teacher motivation, Future professional development.

\section{Introduction}

Since October 2018, the University of Latvia alongside with three other Higher Education institutions (University of Liepaja, University of Daugavpils and Rezekne Academy of Technologies) have been involved in the European Social Fund project 8.2.1. The project aims to reduce the fragmentation of the higher education study programs in the field of 
education, pedagogy and sports in Latvia, by closing a number of existing programs and developing conceptually new programs. Particularly, there will be closed 7 Master level programs during period of 2021-2023 at the faculty of Education, Psychology and Art at University of Latvia and instead of them there will be developed two new Master level programs. One of those Master level programs is "Educational sciences", whose primary target audience are teachers. The Program development began in October 2018 and continues until September 2019.

The new program development always has been influenced by many stakeholders, internally and externally. It is a pressure from society for the Master programme in education to contribute both to the qualification of individual participants and to promote changes in the current school culture and structure. The society hopes that those who complete the Master level course will become "change makers in the school". As we know from the research (Snoek, Enthoven, Kessels, Volman, 2017) it is possible to connect professional development of teachers in the Master level program and school development at the same time. The society has high demands on qualified teachers. The new standard based reforms in Latvia influences it particularly. There is a new demand for teacher professional development as means to enable them to reflect on and critique their own performances, create their own knowledge and attain professional autonomy the same time. Thus, designing the academic Master level education programs, especially for teachers, has high complexity. The Master program for teachers is not a straight forward knowledge transformation. Those programs should be teacher oriented and focused, they have to answer to the learners needs and to be based on teachers current experiences, also should take in consideration the current school's as organization's needs as well.

What is known from the research that the motivation of teachers to participate in programs is an essential element that should be taken into consideration when planning the Master level continuing professional developing/professional learning program (Beresford-Dey, Holme, 2018).

A review of theoretical literature reveals that studies related to students' motivations for attending a specific programme have been conducted for many years, yet there is no extensive research on motivation to study in the Master's level programs (Bozek, B., Raeymaeckers, Spooren, 2017), even less on teachers' motivation to study at Master's level programs in educational sciences.

The latest research that have been conducted internationally, for example, the research in Vietnam (Nghia, 2018) reveals 14 motivations to study in the Master level programs in education. The results of the study show that students choose to study the Master level programme due to 
their passion for learning, the need to acquire knowledge and skills relevant to their targeted/current job, or to challenge their academic competence. They were strongly motivated to attend the Master's programmes also due to employment-related motivations, such as finding a well-paid job, meeting employers' demands for postgraduate qualifications, to get a promotion at their future work, or to continue to be competitive in the labour market. In the research conducted by Israeli scientists (Arar, et al., 2018) there were found that the highest rankings motivation was found for teacher's selfdevelopment, but the next highest ranking was given requirements such as the desire for a higher salary, or motivation induced by pressure from their work places and surroundings. The comparative study for three postsoviet countries - Romania, Poland and Latvia was conducted to find out the motives of student teachers to study in Master's program. (KowalczukWalędziak, et al., 2017) The main motives expressed by the student teachers were to gain deeper knowledge and skills in the field of education, along with enhancing personal development and professional development.

The results provide an understanding that the research can be explained by self -determination theory. The authors Edvard Deci and Richard Rayens argue that people have intrinsic desire to explore themselves, understand and assimilate aspects of their environment. This proactive motivation is present from the very early stages of development, does not depend on external pressures. «People are said to be motivated to the extent that they intend to accomplish something" - that is, to the extent that they have a purpose» (Deci, Ryan, 1994, p. 3). Intrinsic motivation helps the natural human propensity to learn and assimilate (Ryan, Deci, 2000). Intrinsic motivation results in high-quality learning and creativity. Therefore, intrinsic motivation for learning would always be the most important. At the same time extrinsic motivation which can reflect external control or true self-regulation are important for learning too. As it was concluded by both authors after their empirical research that both - intrinsic and extrinsic motivation are important for optimal learning (Deci, Ryan, 1994). As found in studies (Nghia, 2018, Arar, et al., 2018), teachers' motivation to study in the Master's program is primarily intrinsic, but the importance of external motivation should not be underestimated.

So far there has been published comparative study examining Polish, Romanian and Latvia's student teacher's perspective to study in Master level programs (Kowalczuk-Walędziak, et al., 2017). The part of the mentioned research questioner was devoted to motives for choosing master's program. But there have been not published research specifically concerning teacher's motivation to study in Master level program in Latvia, therefore understanding teachers' study motivations in Master level program can be used as a guide to develop the teacher centred master level programme. 
The aim of the article is to identify the teachers' motivations to study in Master level program "Educational sciences".

The researchers explore the motivation (intrinsic and extrinsic) of teachers to study in the Master's programs in education science and provide suggestions to be taken into account by designing the comprehensive Master level program from that.

\section{Methodology}

The study was conducted as a mixed method case study. It took place in Latvia from 2018, October to 2019, May, alongside the development of the Master level program "Educational sciences" in the University of Latvia. At first phase it included 14 semi structured interviews with the heads or deputy-heads of 8 mainstream schools (different regions and types of schools) and 2 teachers recently obtained the Master's degree. There were studied "School quality indicators" (233) alongside. After analyses of theoretical literature and acquired results in the first phase (results from semi structured interview and analyses of "School quality indicators") there were developed a questioner (see Figure 1) and organized a survey $(\mathrm{N}=186)$ administered for educators and the students from bachelor level teacher education programs.
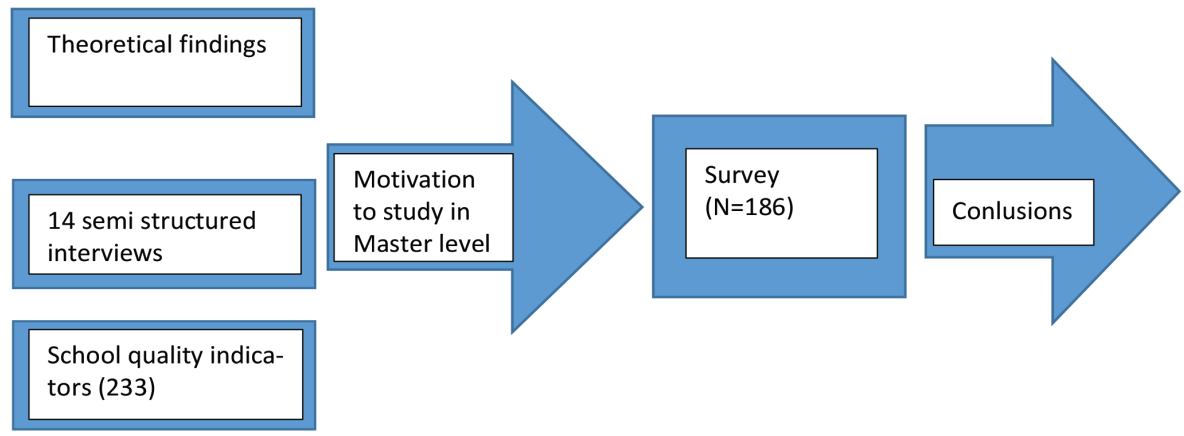

Figure 1. Research design

The survey included 33 questions. In this paper there are analysed four questions related to teacher motivation to study in the Master level program. The survey was designed in Google platform and was distributed online through several channels - emails, Facebook, WhatsApp. The University of Latvia and the project partners participated in the distribution of survey. There were set time limits (three weeks) for distribution and data collection of the survey. After receiving the data there were used descriptive statistical data processing method and descriptive analyses. 
Participants of survey. Majority of survey's respondents were in at the age from 25 up to 50 years old (together 65,4\%), which is the main target audience's age for the Master level studies. Majority of respondents have a working experience from 5 years up to 20 years at school (See Figure 2).

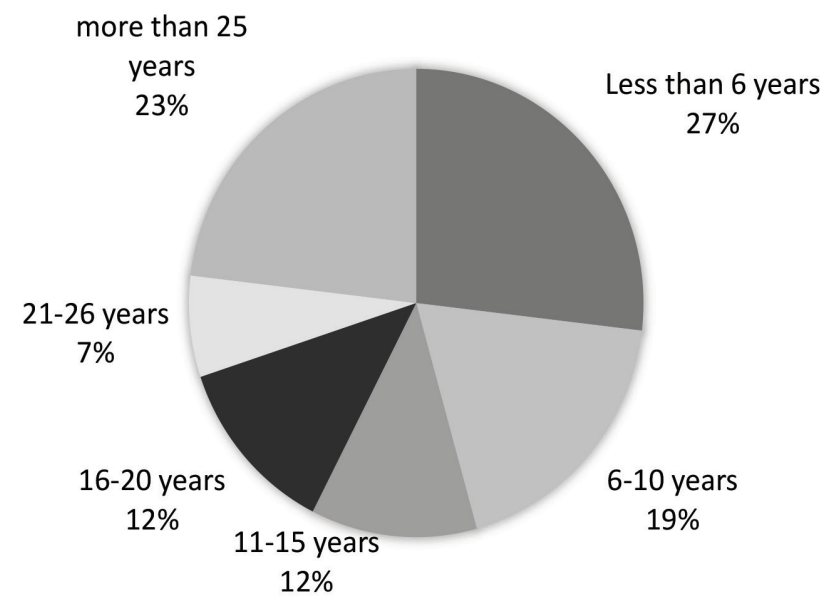

Figure 2. Respondents' current work experience in the education

The main part of the respondents are employed in the primary $(34,4 \%)$ or in the secondary school $(21,5 \%)$.

$41,4 \%$ of respondents admitted that they are interested to study in the Master's level program, only 8,6\% of respondents responded that they are not interested for future studies in the Master's level programs. 37,6\% of respondents answered, that they already have Master degree. The data reveals that most of the teachers who do not have the Master's level education are interested for their further studies.

\section{Results}

\section{Results of the $1^{\text {st }}$ phase}

The researchers started by studying externally formulated quality indicators according to which the quality of every educational institution in Latvia is described and evaluated (SEQS/IKVD, n.n.). Analysis of 233 indicators applied for evaluation of schools in Latvia shows that 69 (about 20\%) of them are related to the competencies that are specific to the Master's level education, other $80 \%$ - to teachers' professional competencies or their management skills. The Figure 3 illustrates the proportion of the key areas (number of indicators) whose quality is 
determined by the professional competence at the Master's level and justifies the conclusion that the areas in which education the Master's competencies are most needed are process analysis, evidence-based institution development planning, as well as expertise and mastery in methodological leadership.

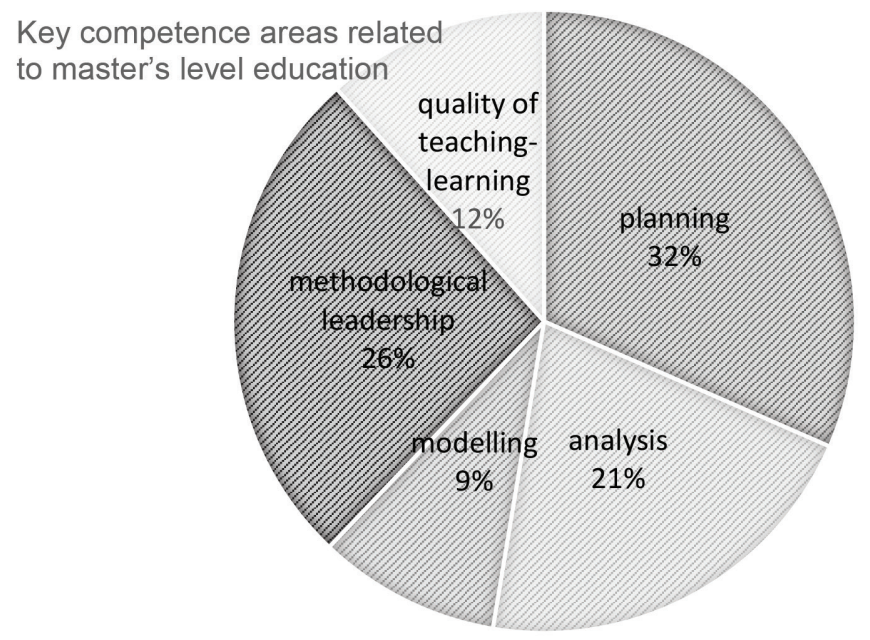

Figure 3. Formal quality indicators related to Master studies

The results of conducted semi structured interviews revealed that the Master's degree at school is not required neither by the profession standard, nor it affects directly the teacher's financial conditions. The Master's level education is not required by regulation or any external conditions. However, taking into account the demands of modern education - moving towards competence approach and increasing an autonomy of the schools, managing modern educational processes and implementing inclusive education - the Master's level competencies for teachers and educators in general education have become crucial to ensure the evidence-based quality education, innovation and school development in the changing contexts. There are clearly required such competences as: process planning, evaluation, forecasting; methodological leadership; ability to act / think / plan / analyse interdisciplinary; ability to analyse the effectiveness of educational processes; evidence-based development planning (including ability to contextualize and use the results of current research in the field); 'big picture' thinking in education. The key-term of the Master's level education should be internal discipline. Taking into account the direction of education policy to competencies based education, education institutions demand change agents understanding and learning the essence of actual education changes as well as implementing them 
in real contexts (considering the lack of educators, aging, technological possibilities, etc.), fostering internal discipline by working in teams, especially concerning inclusive education, which is actual for education policy in Latvia and requires effective collaboration of the whole school personnel.

Thus, despite the real (pragmatic considerations) situation in educational institutions to implement reform plans, educators have the opportunity to improve their academic and professional potential in the Master's level programs. It is also related to the provision of pedagogical professional development opportunities, which, in parallel with the broad offer of further education courses and regulations for the further education of teachers, provide an opportunity to significantly increase the qualification of educators, directs to higher academic / professional level activities and purposefully prepares specialists for work in uncertain situations that are topical for education reforms (can generate new ideas, evaluate their implementation risks, use methodologically sound reasoning, evaluating situations / results / opportunities).

\section{Results of the $2^{\text {nd }}$ phase}

After the conducted or provided analyses of formal quality indicators and semi structured interviews results, taking into consideration literature review, there was made a set of 23 motivations for teachers to study in the Master's level programs. The possibility to add teachers own motivation to the list was provided. There were both intrinsic and extrinsic motives included in the list. Intrinsic motives: self-realization, to get broader picture an overview and an interdisciplinary view of what is going on in education, to develop pedagogical competencies, to develop leader competencies, to develop researcher competencies, to participate in the planning and implementation of educational processes in an educational institution, evaluation, forecasting skills; to make evidence based analyses of processes at school, to undertake methodological leadership in the school, to become a change leader in education, to spend purposefully the free time, to implement the research projects of interest, to have an opportunity to learn in the Master's level program, to achieve the high quality professional development in the area of interest, to acquire the Master's level education for future studies in Doctoral program, to be ready to start up own business. The extrinsic motives: to have a higher salary, to keep job, to raise status in education institution, to climb the career ladder, to belong to educational institution, as the work in that institution demands a higher level education, to lead a projects, to became a director of the educational institution, to have an opportunity to go abroad for exchange programs. There were no any other motives added from participants to the list. 
Accordingly, the major question to teachers was about their motivation to study in the Master's program "Educational sciences". The survey revealed that the 8 highest ranking of respondents motivation for Master studies in education were: deliberately improve pedagogical competences $(47,8 \%)$ to get broader picture an overview and an interdisciplinary view of what is going on in education (35,5\%), to participate in the planning and implementation of educational processes in school (22,6\%), to improve management/leadership competencies $(21,5 \%)$, to become the leader for change in the education $(15,1 \%)$, to achieve the high quality professional development in the area of interest (15,1\%), to make an evidence based analyses of existing processes at school $(15,1 \%)$, to develop researcher competence $(15,1 \%)$. The all above mentioned motives are intrinsic ones. The 8 lowest ranking of respondent's motivation for the Master's studies in education were: to keep their own job $(2,2 \%)$ and to have an opportunity to go abroad for exchange programs $(2,7 \%)$, to raise their own status in the education institution $(3,2 \%)$, to spend purposefully the free time $(4,3 \%)$, to have a higher salary $(5,9 \%)$, to climb the career ladder $(5,9 \%)$, to lead projects $(5,9 \%)$, to belong to educational institution, as the work in that institution demands the higher level education (6,5\%). Seven of the 8 lowest ranking motives were connected with extrinsic motivation. The results obtained may be explained by the respondents' answer to the next question: whether the teachers were encouraged and motivated to study to the Master's program by the educational institutions in which they work currently. In response to that $29,6 \%$ teachers agreed that they were encouraged and motivated to study in the Master's level program, but $35,5 \%$ admitted that they were not motivated by the institution they work for. The other question was asked to teachers: under which conditions teachers would be willing to study for a Master's degree? The 5 highest ranking answers were: if the studies were interesting and attractive (51,6\%), if there would be a possibility to study for the state budget funds (50,5\%), if it would be possible to solve the existing work problem during the studies $(25,3 \%)$, if there would be a part time studies $(25,3 \%)$, if the studies would be on Fridays and Saturdays $(24,7)$, if it would affect my salary (22\%). The answers provided by teachers still highlight the fact that for intrinsic motives there is high importance, as respondents are willing to have interesting and attractive studies. Nevertheless, the possibility for students to study for the state funded is not less important. It can influence the teacher's decision to study in the Master's level program. 


\section{Conclusions and Implications}

Recognizing the limitations of this study, the case study indicates that the motivation of teachers in Latvia to study the Master's level program is primarily intrinsic one which is consistent with international research (Nghia, 2018, Arar, et al., 2018, Kowalczuk-Walędziak, et al., 2017). Out of the 23 motivations for teachers to study in the Master's level programs there were identified the 8 as most important ones: deliberately improve pedagogical competences, to get broader picture an overview and an interdisciplinary view of what is going on in education, to participate in the planning and implementation of educational processes in school, to improve management/leadership competences, to become the leader of change in the education, to achieve the high quality professional development in the area of interest, to make an evidence based analyses of the current processes at school, to develop their researcher competence. The results of the survey pointed out that external motivation was the least important for teachers. To keep job, to have an opportunity to go abroad for exchange programs, to raise status in education institution where they are employed, to have a higher salary, to climb the career ladder was the least important motivation for teachers to study in the Master's program. As it was explained by respondents of semi structured interviews the Master's degree is not required neither by the profession standard, nor it affect in any way the teacher's financial conditions. Only fourth part of the respondents agreed that they were encouraged and motivated to study Master's program by the educational institutions in which they work. If compare it with international studies (Nghia, 2018, Arar, et al., 2018) in other countries teachers have given greater importance to external motives than in Latvia. Consequently, we can conclude that the teacher's extrinsic motivation to study the Master's level program in the education is closely associated with existing political, socio-economic, cultural and educational characteristics of Latvia's current state and demands from society.

Although the intrinsic motivation is the most important for teachers to study the Master's level programs in Latvia the designers and supporters of the program should be considering that half of the respondents agreed that the studies should be interesting and attractive and there should be a possibility to study using the state budget funds for this purpose. Many teachers would be interested to solve the existing work problem during the studies. Almost fourth part of the respondents would be interested in the part time studies and to have lessons on Fridays and Saturdays. Only the fifth part of the teachers admitted that they would be interested to study if the studies affect their salary. So we can conclude that the motivation of teachers to study in the Master's level program is primarily intrinsic one but 
opportunity to study using the state budget resources would significantly increase respondents' interest for studies.

According to the results the Master's program "Education Science" is developed by taking into consideration the program objectives, by clarification the concept of the program, content and possible forms of studies.

\section{References}

Arar K., Zuzovsky R., Donitsa-Schmidt, S., Trumper R. \& Barak, J. (2018). Teachers' Motivations for Master's Degree Programs in Education in Israeli Teacher Training Institutions and the Implications for Government Policy-making Concerning those Programs. Asia-Pacific Journal of Teacher Education. Doi: https://datubazes.lanet.lv:487 6/10.1080/1359866X.2018.1542661.

Bozek, B., Raeymaeckers, P., Spooren, P. (2017). Motivations to become a master in social work: a typology of students. European Journal of Social Work, Volume 20, Issue 3, Pages 409-421 Doi: https://datubazes.lanet.lv:4876/10.1080/13691457.201 7.1283587.

Beresford-Dey, M., Holme, R. (2018). Optional Assessment Submission within Master'slevel Learning: Teachers' Perceptions. Professional development in education, Volume 44, Issue 3, 428-443.

Deci, E. L, Ryan, R. M. (1994). Promoting Self - determinated Education. Scandinavian Journal of Educational research. Volume 38, No 1, 3-14. Accessible: https://www. researchgate.net/publication/248960376_Promoting_Self-determined_Education.

Kowalczuk-Walędziak, M., Clipa, O., Daniela, L. (2017). Do Teachers Really Need a Master's Degree? Student Teachers' Perspectives// Journal of Educational Sciences 1(35), p. 38-58.

Ryan, R. M., \& Deci, E. L. (2000). Intrinsic and Extrinsic Motivations: Classic Definitions and New Directions. Contemporary Educational Psychology, 25(1), 54-67. Accessible: https://mmrg.pbworks.com/f/Ryan, + Deci + 00.pdf.

Nghia, T., L. H. (2018). Vietnamese Students' Learning Motivations for Master's Programmes: Implications for Curriculum Development and Pedagogical Practice ORCID Icon. Journal of Further and Higher Education. Doi: https://datubazes.lanet.lv:4876/10.1 080/0309877X.2018.1444742.

Snoek, M., Enthoven, M., Kessels, J., Volman, M. (2017). Increasing the Impact of a Master's Programme on Teacher Leadership and School Development by Means of Boundary Crossing. International Journal of Leadership in Education, Volume 20, Issue 1, 26-56. Doi: https://datubazes.lanet.lv:4876/10.1080/13603124.2015.1025855.

SEQS/IKVD (n.n.). Metodiskie ieteikumi profesionālās izglītības un vispārējās izglītības iestāžu pašvērtēšana [Methodological recommendations for Self-assessment of vocational education and general education institutions] Retrieved from: http://viaa. gov.lv/library/files/original/06_IKVD_Metod_ieteik_pasvertesanai_upd.pdf. 